\title{
BREVES REFLEXÕES SOBRE A LEI TIPIFICADORA DA PRÁTICA DE TORTURA (LEI N. 9.455, DE 7 DE ABRIL DE 1997) À LUZ DA ANTIJURIDICIDADE CONCRETA
}

\author{
Andréa Galhardo Palma \\ Aluna do Curso de Graduação da Faculdade de Direito da Universidade de São Paulo
}

\begin{abstract}
Resumo:
Os comentários a seguir se destinam à analise dos principais aspectos da recente "Lei de Tortura" (Lei n. 9.455/97), publicada em 07 de abril de 1997, sua forma de elaboração, conteúdo e reflexos no sistema penal brasileiro. Enfocam a necessidade de uma lei desse porte, garantidora da dignidade humana, sem deixar de criticar, sobre o aspecto da tipificação, a forma assistemática pela qual adentrou no ordenamento jurídico nacional. Comenta, logo após, artigo por artigo da lei.
\end{abstract}

Abstract:

The comment below destinates to analyze the main aspects of recent "Torture Law" published in april 7th, 1997; its elaboration, meaning and reflexion at brazilian penal system. The comment also focalizes the need of a law such of size, that can guarantee human dignity, and at same time criticize this law under its characterization in brazilian legal organization. Following there are comments of article by article of law.

Unitermos: antijuridicidade; tortura; entorpecente; anistia.

A Lei n. 9.455/97, na esteira do mandamento constitucional constante do art. $5^{\circ}$ inciso XLIII: "a lei considerará crimes inafiançáveis e insuscetiveis de graça ou anistia a práitica de tortura, o tráfico ilícito de entorpecentes e drogas afins, o terrorismo e os definidos como crimes hediondos, por eles respondendo os mandantes, os executores e os que, podendo evitá-los, se omitirem.", vem regulamentar, num "espasmo legislativo" do Congresso Nacional, a tão-esperada lei antitortura, cujo projeto tramitava naquele desde 1994, juntamente com estudos do Ministério da Justiça que tratavam da definição do crime de tortura.

Inegável a casuística penal à promulgação da nova lei. Em outros termos, irrefutável a influência dos recentes episódios ocorridos em Diadema/SP e no Estado do Rio de Janeiro - violência, mortes e arbitrariedades praticadas por 
policiais militares, com respaldo na certeza da impunidade. Daí falarmos em espasmo, em resposta súbita, a um acontecimento penal.

Alguns juristas criticaram a forma como a lei entrou no sistema jurídico-penal, levantando dúvidas quanto à legitimidade desse processo de tipificação, in verbis: "É lamentável ter vindo a reboque da tragédia de Diadema. E a rapidez do Congresso nessas circunstâncias impõe duas perguntas aos parlamentares: se o projeto já estava devidamente discutido, por que não tinha sido aprovado? Se não foi bem discutido, como é que foi aprovado em tão-pouco tempo? (Sérgio Salomão Shecaira, presidente do Instituto Brasileiro de Ciências Criminais IBCCrim, em entrevista publicada em 12 de abril de 1997, no jornal Folha de São Paulo, p. 3-2).

Antes de adentrarmos na exposição da lei, seguida de breves comentários, mister se faz consignar que a incriminação da tortura segue, abstraindo os malefícios da casuística legiferante, a tendência internacional do Direito Penal e Processo Penal das Garantias Individuais do Cidadão, seja ele agente ou sujeito da prática delituosa.

Sob a égide da legalidade, da ampla defesa, do julgamento em tempo razoável, da fundamentação das prisões, quer-se a Justiça penal efetiva, célere e eficaz. É o que se infere da chamada Convenção Americana sobre Direitos Humanos (Pacto de São José da Costa Rica), em todo o teor do seu art. $8^{\circ}$ e seguintes, ratificada pelo Brasil, através do Decreto n. 678, de 06 de novembro de 1992. Portanto, agora, lei interna, conforme art. $5^{\circ}, \S 2^{\circ}$ da Constituição Federal vigente.

Sabemos da condicionalidade histórico-cultural que sofre o Direito Penal, da influência da chamada política criminal, nem sempre utilizada como ciência, na luta contra o fenômeno da criminalidade (v. Condicionalidade Sóciocultural do Direito Penal, Américo A. Taipa de Carvalho, Coimbra 1985, pp. 13, 89 e ss.); da importância da inserção do legislador na consciência ético-social para tipificar condutas.

Entretanto, esta condicionalidade, que se quer respeitada, nada tem a ver com as manifestações eleitoreiras e pautadas de conveniência e oportunidade que assolam a atividade legislativa do nosso país.

Ora, o caminho que se percorre à elaboração de uma norma penal constitui o momento culminante de um processo, no qual estão em contínua tensão fato e valor. É a idéia de que o direito é o reflexo das condições sociais e culturais, como escreve Bangolini, citado pelo professor Miguel Reale em sua obra 
Antijuridicidade Concreta (p. 6) "os conceitos juridicos e os conceitos do justo são de natureza prevalecentemente histórico-cultural, ancorados que estão ao terreno cultural que os condiciona, na função e aplicação" O direito é fato, valor e norma...

E, complementa o professor Reale, demonstrando que a antijuridicidade tem seu primeiro esteio e real conteúdo no plano ético-social, na concreta realidade de um povo, em determinado tempo e lugar. (Miguel Reale, in Antijuridicidade Concreta, p. 26). Propugna, o autor, uma ordem inerente que condiciona o direito positivo (a norma posta pelo órgão estatal competente). Fala-se do proibido pré-normativo, e aí pensamos na tortura, agora crime, antes prática sempre considerada amoral, injusta e violadora da dignidade humana. A sua antijuridicidade adveio da experiência, da história mesma do Brasil.

E, para que se assente o conceito de condicionalidade e concretude do direito, existente antes mesmo de ser produto legislativo, de uma vontade política, e se entenda a importância da tarefa legislativa de conformação de valores, é necessário um trabalho sério, assaz, jurídico-sociológico, e não repercussionista (representada no binômio cenário de violência, clamor popular versus exasperação de pena), a fim de não criarmos um elastério de normas inaplicáveis por falta de coerência com o ordenamento jurídico.

Esta visão é descortinada por Welzel, em observação sintética, mas completa do fenômeno "o normativo e o real estão entrelaçados, pois a viabilidade do direito depende da conformidade do concreto (real) ao abstrato (normativo)" (Welzel, in Mas alla del derecho natural, p. 41).

Enfim, pretende-se dizer com essa incursão acadêmica, que o Direito Penal a despeito de ser histórico, conjuntural, não se faz da noite para o dia.

A elaboração do tipo (que elucida e esclarece o conteúdo das estruturas normativas, o âmbito do permitido e proibido, e satisfaz a exigência política do nulum crimen sine lege), como ensina o professor Miguel Reale Jr. em suas aulas ministradas nas Arcadas (v. tb. sua obra Parte Geral do Código Penal Nova Interpretação, p. 24, ed. Revista dos Tribunais) tem seu substrato na realidade fenomênica: o legislador da realidade constrói o modelo o qual se amoldará ao comportamento futuro, através de dados elementares na antijuridiciade concreta!. Toda a estrutura normativa traz em si um significado axiológico, que em última análise determinará o que seja justo ou injusto. 
Observa-se, ao voltarmos os olhos para a forma como são elaboradas as leis no Brasil, que a construção teórica, a técnica, o estudo acurado dos planos de elaboração das normas, mormente as de caráter penal, cai no vazio deontológico, isto é naquilo que deveria ser e não é.

Verifica-se no país um total esquecimento da idéia de sistema, de elaboração científica do tipo (com elementos descritivos, normativos e a carga sancionatória...). Esta constatação não é nossa, diga-se de passagem, mas descortinada nas insubstituíveis aulas de Processo Penal ministradas pelo professor Sérgio Marcos de Moraes Pitombo, o qual trata da obviedade do problema, que por ser óbvio, torna-se pouco apreensível aos "operadores" (termo em voga) do direito.

Esta crítica precede o exame, artigo a artigo da nova lei, pela necessária missão de que é preciso estarmos atentos, ainda nos bancos escolares, da tarefa de primarmos, seja na atividade postulatória, seja na decisória, pela boa técnica, não-tecnicismo, reveladora de um Direito Penal garantidor da segurança e certeza jurídicas.

\section{A lei artigo por artigo.}

Art. $1^{\circ}$ Constitui crime de tortura:

I Constranger alguém com emprego de violência ou grave ameaça, causando-lhe sofrimento físico ou mental:

a) com o fim de obter informação, declaração ou confissão da vítima ou de terceira pessoa;

b) para provocar ação ou omissão de natureza criminosa;

c) em razão de discriminação racial ou religiosa;

II submeter alguém, sob sua guarda, poder ou autoridade, com emprego de violência ou grave ameaça, a intenso sofrimento físico ou mental, como forma de aplicar castigo pessoal ou medida de caráter preventivo.

Pena: reclusão de 2 (dois) a 8 (oito) anos.

Parágrafo $1^{\circ} \quad \mathrm{Na}$ mesma pena incorre quem submete a pessoa presa ou sujeita a medida de segurança a sofrimento físico, por intermédio da prática de ato não previsto em lei ou não resultante de medida legal.

Parágrafo $2^{\circ}$ Aquele que se omite em face dessas condutas, quando tinha o dever de evitá-las ou apurálas, incorre na pena de detenção de um a quatro anos. 
Parágrafo $3^{\circ}$ - Se resulta lesão de natureza grave ou gravíssima, a pena é de reclusão de quatro a dez anos; se resulta morte é de oito a dezesseis anos.

Parágrafo $4^{\circ}$ Aumenta-se a pena de um sexto até um terço:

I se o crime é cometido por agente público;

II se o crime é cometido contra criança, gestante, deficiente e adolescente;

III se o crime é cometido mediante seqüestro.

Parágrafo $5^{\circ}$ A condenação acarretará a perda do cargo, função ou emprego público e a interdição para seu exercício pelo dobro do prazo da pena aplicada.

Parágrafo $6^{\circ} O$ crime de tortura é inafiançável $e$ insuscetivel de graça ou anistia.

Parágrafo $7^{\circ} O$ condenado por crime previsto nesta Lei, salvo na hipótese do parágrafo $2^{\circ}$, iniciará o cumprimento da pena em regime fechado.

Art. $2^{\circ}$ - $O$ disposto nesta Lei aplica-se ainda quando o crime não tenha sido cometido em território nacional, sendo a vítima brasileira ou encontrando-se o agente em local sob jurisdição brasileira.

Art. $3^{\circ}$ Esta Lei entra em vigor na data de sua publicação.

Art. $4^{\circ}$-Revoga-se o art. 233 da Lei $n .8 .069$, de 13 de julho de 1990 - Estatuto da Criança e do Adolescente.

Comentários:

Inflacionou o legislador o art. $1^{\circ}$ da Lei, concentrando neste tanto as condutas dolosas (incisos I e II) com pena de reclusão, a conduta comissiva por omissão (parágrafo $2^{\circ}$ ) apenada com detenção, como as agravantes dos parágrafos $3^{\circ}$ (na verdade, trata-se de qualificadora, se resulta lesão de natureza grave ou gravíssima pena de reclusão, quatro a dez anos ou morte, pena de reclusão de oito a dezesseis anos) e $4^{\circ}$ (trata das causas de aumento de pena, variando-se de $1 / 6$ a 1/3), 
parecendo a um observador pouco atento um único tipo, quando, na verdade, a tipificação da tortura é ampla e distinta em cada segmento normativo.

$\mathrm{O}$ inciso I, por exemplo, destaca o elemento subjetivo do injusto, o dolo, a finalidade da tortura, para que esta se configure como crime. Não basta constranger alguém, com emprego de violência ou grave ameaça, causando sofrimento físico ou mental. Já no inciso II, o elemento do tipo em destaque é o normativo-dependente de juízo valorativo encontrável em outras normas jurídicas ou ético-sociais (...) sob sua guarda poder ou autoridade, a intenso sofrimento físico ou mental (...).

Prevê ainda o mesmo artigo, a tortura por omissão. Aquele que sabendo da prática e tendo o poder e o dever legal de evitá-la, não o faz, concorre na qualidade de sujeito ativo do resultado delituoso ao qual não deu causa diretamente. A pena, neste caso é de detenção.

O parágrafo terceiro incrimina o preterdolo com alteração significativa na quantidade da pena cominada (reclusão de quatro a dez anos para lesões e oito a dezesseis anos para o resultado morte). Trata-se a meu ver de qualificadora. Já o parágrafo $4^{\circ}$ como já mencionado, trata das causas de aumento que variam segundo a qualidade do sujeito ativo do delito (agente público veja-se os efeitos da condenação no parágrafo $5^{\circ}$ ) ou do sujeito passivo, criança, gestante, deficiente e adolescente.

É de se notar que, quanto às crianças e os adolescentes, o ECA (Estatuto da Criança e do Adolescente, Lei n. 8.069, de 13 de julho de 1990), já havia incriminação da tortura no art. 233, in verbis: "Submeter criança ou adolescente sob sua autoridade, guarda ou vigilancia a tortura: pena de um a cinco anos." A despeito de ser uma lei especial em face da lei antitortura, esta, inquestionavelmente, sendo posterior, revogou expressamente art. 233, eliminando eventual questão sobre conflito aparente de normas.

Uma questão importante: não descreve a lei o que venha a ser sofrimento físico e mental, o que reclamará do juiz intensa atividade interpretativa, fora do âmbito jurídico-penal...

Numa outra ordem de idéias, a tortura sendo crime inafiançável e insuscetível de anistia ou graça, em conformidade com disposto no art. $5^{\circ}$ inc. XLIII da Constituição Federal, tal qual os crimes hediondos paira a questão: cabe fiança ou liberdade provisória para este tipo de crime? E a progressão do regime prisional? 
A lei nova silencia, mas a Lei dos Crime Hediondos expressamente proíbe a concessão do benefício da liberdade provisória ao acusado e progressão do regime ao condenado. É a inteligência do art. $2^{\circ}$ e $\S \S$ da Lei n. 8.072/90. Parece que a discussão sobre a constitucionalidade ou não do dispositivo em relação à nova lei terá os mesmos moldes da ensejada por ocasião da promulgação dos crimes hediondos. Com relação a estes, o Supremo Tribunal Federal já afirmou em algumas turmas não ser inconstitucional (STF HC 69603-1 Rel. Paulo Brossard; HC 696571/DJU 18.06.93, Rel. Francisco Resek, e RTJE 82/27). É possível a interpretação analógica do dispositivo processual em prejuízo do réu?

A última questão pertine com a extraterritorialidade da lei posta em vigor. $\mathrm{O}$ art. $2^{\circ}$ estende a jurisdição brasileira a qualquer país estrangeiro onde ocorra crime de tortura, que tenha como vítima pessoa de nacionalidade brasileira (critério da personalidade da lei) ou em razão do agente (torturador) encontrar-se em território nacional, ainda que tenha praticado o delito no estrangeiro. Por ser uma lei também resultante de convenção internacional, justifica-se a competência do Brasil para repressão da tortura, de acordo com o disposto no art. $7^{\circ}$, inciso II e $\S 2^{\circ}$ do Código Penal, condicionando a punibilidade do agente a sua entrada em território nacional.

Estas são, num relance de olhos à recente Lei, as principais observações e indagações a serem feitas. Desde já fazemos votos que efetivamente produza resultados, não-só como remédio à enfermidade forjada desde de há muito na história política (repressiva) brasileira, mas como efetivo instrumento do que a Carta Constitucional erigiu à categoria de um dos princípios fundamentais do Estado de Direito: a dignidade da pessoa humana. Em outras palavras, urge tornar clara a função vital do Estado, a de velar pelo direito.

Velar pelo direito, eis a função vital do Estado. (Jhering)

São Paulo, novembro de 1997. 
Bibliografia

ALMEIDA, Joaquim Canuto Mendes de. Princípios fundamentais do processo penal. São Paulo: Revista dos Tribunais, 1973.

CARVAlHO, Américo A. Taipa. Condicionalidade sócio-cultural do Direito Penal. Portugal: Ed. Coimbra, 1985.

REALE JR, Miguel. Antijuridicidade concreta. São Paulo: Ed. Bushatsky, 1974. Tribunais, 1988. Parte Geral do Código Penal. São Paulo: Ed. Revista dos

REALE, Miguel. O direito como experiência. São Paulo, 1968.

SHECAIRA, Sérgio S.. Folha de S. Paulo, 12.04.1997. p. 3.2.

WELZEL, Hans. Mas ala del derecho natural. 1941. 